\title{
Role of Endoscopic Imaging (I Scan) in the Diagnosis of Gastritis
}

\author{
AYMAN YOUSY, M.D.*; HANY SHEHAB, M.D.*; KHALED RAGAB, M.Sc.**; \\ MAGED EL-GHANAM, M.D.**; MOHAMED GODA, M.D.**; HAYTHAM ABDALLA, M.D.**; \\ TAREK ABOUSHOUSHA, M.D.*** and NOHA HELAL, M.D.*** \\ The Department of Endemic Medicine, Hepatology \& Gastroenterology, Faculty of Medicine, Cairo University*, \\ The Departments of Hepatology \& Gastroenterology** and Clinical Pathology***, Theodor Bilharz Research Institute
}

\begin{abstract}
Background: Gastritis: Defines any (histologically confirmed) inflammation of the gastric mucosa. Worldwide, the epidemiology of gastritis overlaps that of Helicobacter pylori infection, which affects approximately $50 \%$ of the world's population. The aim of the current study was to investigate the value of I-scan in diagnosis gastritis whether HP positive or negative.
\end{abstract}

Subjects and Methods: This study included 164 patients divided into three groups. Group (1) included 12 normal subjects, Group (2) 101 helicobacter pylori positive subjects with gastritis and Group (3) 51 helicobacter pylori negative subjects gastritis. Upper endoscopy was performed for all cases, first by WLE then we shifted to I scan technology. Two biopsies were taken, one from greater curvature of the body of stomach and the other from antrum). All patients were assessed clinically, biochemically, viral markers and by ultrasound

Results: In the helicobacter pylori positive gastritis we found that absence of collecting venule and Subepithelial Capillary Net Work (SECN) had good sensitivity $93 \%$ and poor specificity $32 \%$.

Conclusion: I scan has poor specificity in diagnosis of HP gastritis.

Key Words: I scan - Helicobacter pylori-Gastritis.

\section{Introduction}

ALTHOUGH chronic gastritis will develop in nearly all individuals who are persistently colonized with $\mathrm{H}$. pylori, $80 \%$ to $90 \%$ will never experience symptoms or develop clinical disease [1] . It has not been clearly established how the presence of H. pylori leads to gastric and duodenal ulcers, but disruption of gastric and duodenal mucosal integrity seems to involve a complex interaction between the host and pathogen [2]. Individuals with duodenal

Correspondence to: Dr. Ayman Yousy, The Department of Endemic Medicine, Hepatology \& Gastroenterology, Faculty of Medicine, Cairo University ulcers who are also infected with H. pylori have been shown to have a high rate of gastric acid secretion, with a basal acid output that is 3 times higher than un-infected individuals. These individuals with acid hyper secretion are more likely to have antrum predominant gastritis, whereas those with lower acid secretion are more likely to have diffuse gastritis or inflammation predominantly confined to the body of the stomach. Low acid secretion might predispose patients to gastric ulcer and, in some cases, lead to gastric carcinoma [3] When an endoscopy is performed, it now becomes easier to observe indirect evidence of the presence of $\mathrm{H}$. pylori infection, given the progress of new methods including magnifying narrow band imaging or con-focal laser endo-microscopy. Out of the biopsy-based tests, the original method proposed concerned culture in a broth medium with or without antibiotics and ELISA detection of $\mathrm{H}$. pylori. The combination of pepsinogen detection to $\mathrm{H}$. pylori serology is now more and more evaluated to detect pre-neoplastic lesions [4]. Other forms of gastritis include, autoimmune gastritis, chemical gastritis, infections other than helicobacter pylori and eosinophilic gastritis [5]. New endoscopic technology including high-resolution magnifying endoscopy and magnifying endoscopy with Narrow-Band Imaging (NBI), have shown great promise for the diagnosis of $\mathrm{H}$. pylori infection on the basis of gastric mucosal and vascular patterns [6] Recently, a high definition endoscope combined with (I-scan) has been developed, which can provide clear images of the mucosal and vascular patterns [7]

\section{Subjects and Methods}

A total of adult 164 patients of both gender were included in this study who were presented to the Endoscopy Unit, Theodor Bilharz Research 
Institute (TBRI), Giza, Egypt and BVU Endoscopy Unit, Istanbul, Giza. The study was carried out from January 2014 till November 2016. Ethical approval was obtained from the TBRI-Institutional Review Board (IRB). The informed consents were obtained from all the patients recruited in the study. The age of the included patients ranged from 1870 years old. All the included patients had an indication for upper endoscopy (i.e. dyspepsia) and any patients with active hematemesis or melena or previous gastric surgery were excluded.

The included patients were classified into three groups based on the histological finding; Group (1) formed of 12 patients with normal histological finding while Group (2) formed of 101 patients with HP gastritis Group (3) 51 patients HP negative gastritis.

\section{Procedure:}

A full history, clinical examination and ChildPugh grading for cirrhotic patients were performed for all the patients. Also a complete blood picture, ESR , hepatic profile (serum bilirubin, ALT, AST, alkaline phosphatase, serum albumin, prothrombin time \& concentration), renal biochemical profile, serum alpha fetoprotein and abdominal ultrasound (to detect liver texture, size, and the condition of the portal vein as well as the presence of Focal Hepatic Lesion (FHL) were performed. For upper endoscopy; all procedures were performed by a single endoscopist (conventional White Light Endoscopy (WLE) was used followed by (I-scan) and two gastric biopsies were taken, one from body and one from antrum. All procedures were recorded as high-definition video. (I-scan) examination was performed in two main sites: Gastric antrum and body. The (I-scan) endoscopy is HD image using Pentax.

After finishing the examination; two biopsies one from the antrum and the other from body greater curvature were taken and preserved in formalin for histological examination. The observed mucosal and vascular pattern by I-scan were correlated with the histopathological results. Fifty of recorded videos were reviewed by an expert endoscopist and inter-observer agreement was calculated.

\section{Statistical methods:}

Data were coded and entered using the statistical package SPSS Version 21. Data was summarized using mean, standard deviation, median, minimum and maximum for quantitative variables and frequencies (number of cases) and relative frequencies (percentages) for categorical variables. Comparison of quantitative variables was done using the nonparametric Kruskal-Wallis when comparing more than 2 groups and using the non-parametric MannWhitney U test when comparing 2 groups. Comparison between the different study groups using chi-square tests. $p$-value $<0.05$ was significant.

\section{Results}

Table (1): Body collecting venule.

\begin{tabular}{|c|c|c|c|}
\hline & Value & df & $p$-value \\
\hline Pearson chi-square & 335.291 (a) & 8 & 0.000 \\
\hline Likelihood ratio & 323.064 & 8 & 0.000 \\
\hline $\mathrm{N}$ of valid cases & 164 & & \\
\hline \multirow[b]{2}{*}{ Body CV } & \multicolumn{3}{|c|}{ Group } \\
\hline & Normal & $\begin{array}{l}\text { HP (-)ve } \\
\text { gastritis }\end{array}$ & $\begin{array}{c}\mathrm{HP}(+) \mathrm{ve} \\
\text { gastritis }\end{array}$ \\
\hline \multicolumn{4}{|l|}{ Absent: } \\
\hline Count & 1 & 45 & 94 \\
\hline$\%$ & $8.3 \%$ & $88.2 \%$ & $93.1 \%$ \\
\hline \multicolumn{4}{|c|}{ Present (not congested): } \\
\hline Count & 11 & 6 & 7 \\
\hline$\%$ & $91.7 \%$ & $11.8 \%$ & $6.9 \%$ \\
\hline \multicolumn{4}{|l|}{ Congested: } \\
\hline Count & 0 & 0 & 0 \\
\hline$\%$ & $0.0 \%$ & $0.0 \%$ & $0.0 \%$ \\
\hline \multicolumn{4}{|l|}{ Total: } \\
\hline Count & 12 & 51 & 101 \\
\hline
\end{tabular}

Body CV is present in $91.7 \%$ of normal cases and, absent in $88.2 \%$ of HP negative gastritis and $93.1 \%$ in HP positive gastritis.

Table (2): Body subepithelial capillary net work (SECN).

\begin{tabular}{|c|c|c|c|c|}
\hline \multirow[b]{2}{*}{ Body SECN } & \multicolumn{4}{|c|}{ Group } \\
\hline & Normal & \multicolumn{2}{|l|}{$\begin{array}{l}\text { HP (-)ve } \\
\text { gastritis }\end{array}$} & $\begin{array}{c}\mathrm{HP}(+) \mathrm{ve} \\
\text { gastritis }\end{array}$ \\
\hline \multicolumn{5}{|l|}{ Absent: } \\
\hline Count & \multirow{2}{*}{$\begin{array}{l}1 \\
8.3 \%\end{array}$} & \multirow{2}{*}{\multicolumn{2}{|c|}{$\begin{array}{l}45 \\
88.2 \%\end{array}$}} & \\
\hline & & & & $89.1 \%$ \\
\hline \multicolumn{5}{|l|}{ Present: } \\
\hline Count & \multirow{2}{*}{$\begin{array}{l}11 \\
91.7 \%\end{array}$} & \multirow{2}{*}{\multicolumn{2}{|c|}{$\begin{array}{l}6 \\
11.8 \%\end{array}$}} & \\
\hline$\%$ & & & & $10.9 \%$ \\
\hline \multicolumn{5}{|l|}{ Congested: } \\
\hline Count & 0 & \multicolumn{2}{|l|}{0} & 0 \\
\hline$\%$ & $0.0 \%$ & \multicolumn{2}{|l|}{$0.0 \%$} & $0.0 \%$ \\
\hline \multirow[t]{3}{*}{$\begin{array}{l}\text { Total: } \\
\text { Count }\end{array}$} & 12 & \multicolumn{2}{|l|}{51} & 101 \\
\hline & & \multicolumn{3}{|c|}{ Chi-square tests } \\
\hline & & & df & $p$-value \\
\hline Pearson chi-square & & (a) & 8 & 0.000 \\
\hline Likelihood ratio & & & 8 & 0.000 \\
\hline $\mathrm{N}$ of valid cases & 16 & & & \\
\hline
\end{tabular}


Body SECN were present in $91.7 \%$ of normal group, absent in $88.2 \% \mathrm{HP}$ negative gastritis \& $89.1 \%$ in HP positive group. Congested SECN present in $93.7 \%$ severe PHG \& $86.8 \%$ mild PHG, with a significant $p$-value according to chi square tests.

Table (3): Antral subepithelial capillary net work (SECN).

\begin{tabular}{|c|c|c|c|c|}
\hline \multirow[b]{2}{*}{ Antrum SECN } & \multicolumn{4}{|c|}{ Group } \\
\hline & Normal & \multicolumn{2}{|c|}{$\begin{array}{l}\mathrm{HP}(-) \mathrm{ve} \\
\text { gastritis }\end{array}$} & $\begin{array}{l}\mathrm{HP}(+) \mathrm{ve} \\
\text { gastritis }\end{array}$ \\
\hline \multicolumn{5}{|l|}{ Absent: } \\
\hline Count & \multirow{2}{*}{$\begin{array}{l}1 \\
8.3 \%\end{array}$} & \multicolumn{2}{|c|}{43} & \\
\hline & & \multicolumn{2}{|c|}{$84.3 \%$} & $89.1 \%$ \\
\hline \multicolumn{5}{|l|}{ Present: } \\
\hline Count & \multirow{2}{*}{$\begin{array}{l}11 \\
91.7 \%\end{array}$} & \multirow{2}{*}{\multicolumn{2}{|c|}{$\begin{array}{l}8 \\
15.7 \%\end{array}$}} & \multirow{2}{*}{$\begin{array}{l}11 \\
10.9 \%\end{array}$} \\
\hline$\%$ & & & & \\
\hline \multicolumn{5}{|l|}{ Congested: } \\
\hline Count & 0 & 0 & & 0 \\
\hline$\%$ & $0.0 \%$ & \multicolumn{2}{|c|}{$0.0 \%$} & $0.0 \%$ \\
\hline \multirow[t]{3}{*}{$\begin{array}{l}\text { Total: } \\
\quad \text { Count }\end{array}$} & 12 & \multicolumn{2}{|c|}{51} & 101 \\
\hline & \multicolumn{4}{|c|}{$\begin{array}{l}\text { Chi-square tests between } \\
\text { pathological groups }\end{array}$} \\
\hline & \multicolumn{2}{|c|}{ Value } & df & $p$-value \\
\hline Pearson chi-square & 381 & & 16 & 0.000 \\
\hline Likelihood ratio & 355 & & 16 & 0.000 \\
\hline $\mathrm{N}$ of valid cases & 164 & & & \\
\hline
\end{tabular}

SECN were seen $91.7 \%$ normal group, while it was absent in $84.3 \%$ HP negative and $89.1 \%$ HP positive gastritis, with a significant $p$-value.

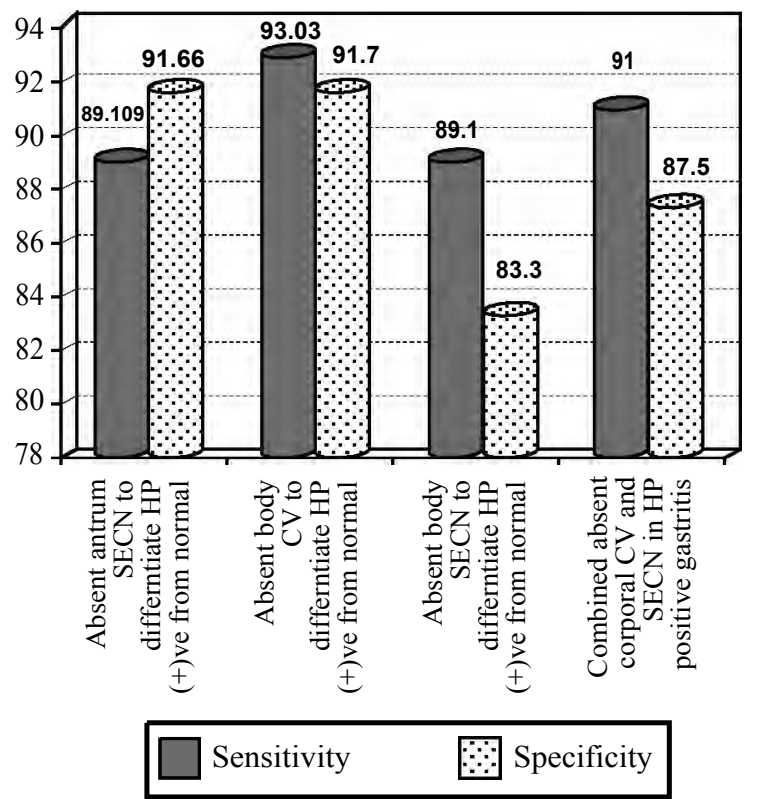

Fig. (1): Vascular pattern by (I-scan) in diagnosis of HP positive gastritis in comparison to normal control.
The sensitivity and specificity of absent of antrum SECN were $89.1 \%$ and $91.6 \%$ respectively. The sensitivity and specificity of absent corporal CV were $93.03 \%$ and $91.7 \%$. And for corporal SECN was $89.1 \%$ sensitivity and $83.3 \%$ specificity. The sensitivity and specificity for combined loss of CV and SECN were $91 \%$ and $87.5 \%$ respectively.

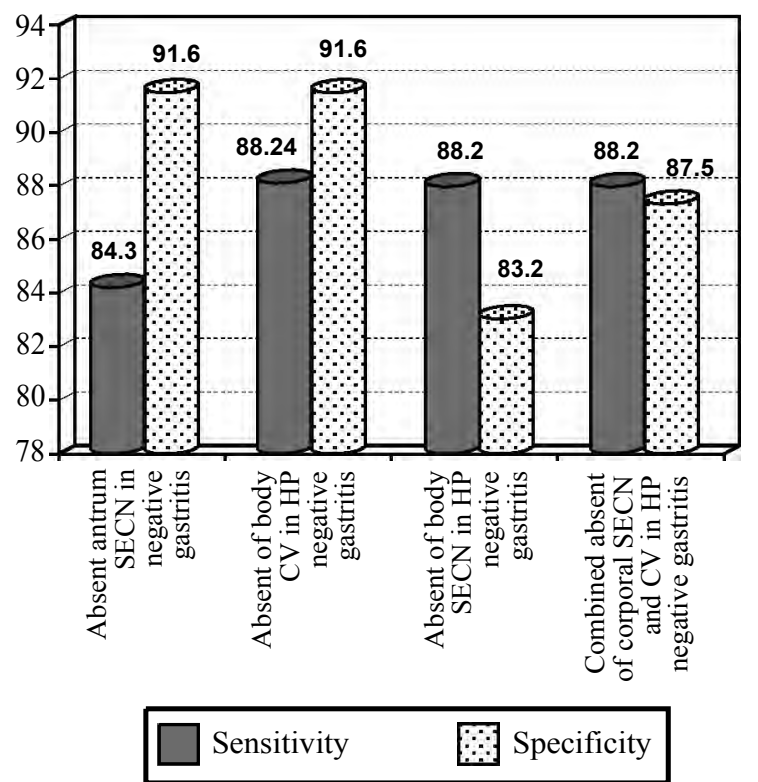

Fig. (2): Vascular pattern by (I-scan) in diagnosis of HP negative gastritis in comparison to normal control.

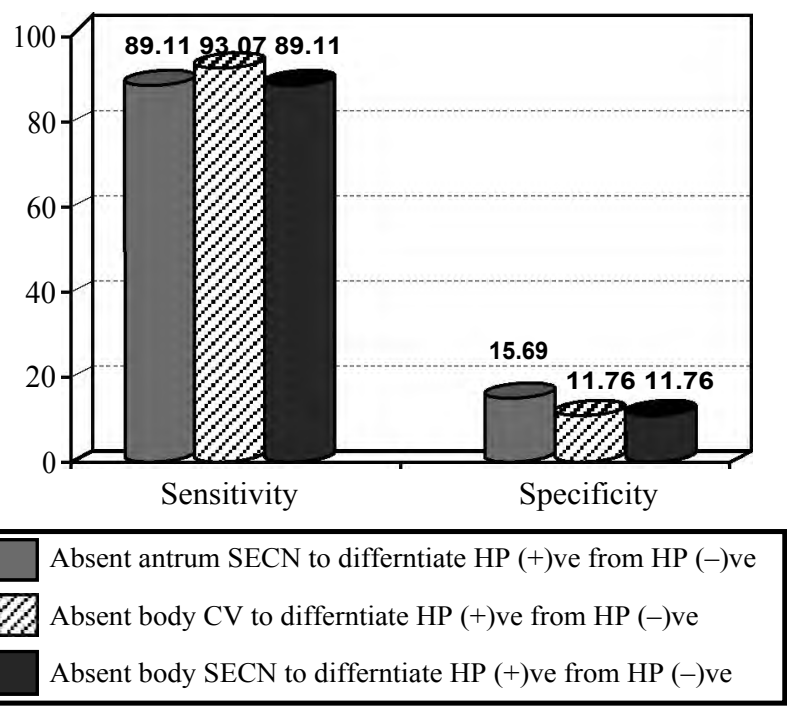

Fig. (3): Vascular patern to diffirentiate HP positive and negative gastritis.

Vascular pattern seen by (I scan) in cases of gastritis (whether HP positive or negative) showed loss of antral and corporal SECN, CV with good sensitivity while it showed poor specificity to differentiate between HP positive and negative gastritis. 


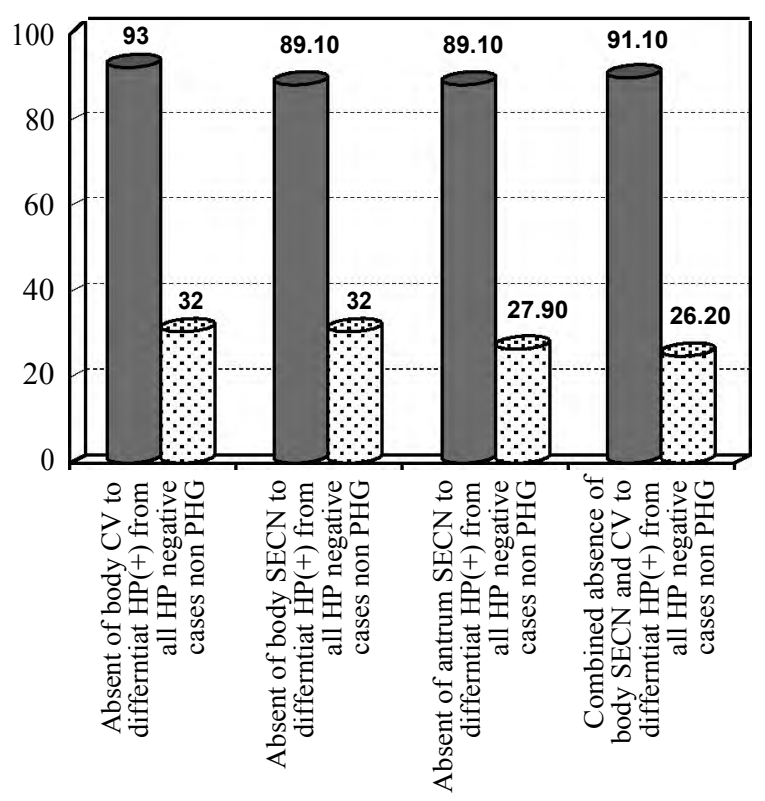

Sensitivity Specificity

Fig. (4): Vascular pattern by I scan in diagnosis of HP positive gastritis in comparison to all HP negative cases (normal and HP negative gastritis).

Vascular pattern by I scan showed good sensitivity in detecting HP gastritis, however, it showed poor specificity in differentiating HP positive from HP negative patients (normal plus HP negative gastritis).

\section{Discussion}

In this study we found nearly the same result with our description of rounded mucosal pattern of the body of stomach with visible honeycomb Subepithelial Capillary Net work (SECN) and spider like Collecting Venules (CV) in $91.7 \%$ of normal cases, in the antrum tubular mucosal pattern $100 \%$ and visible SECN in $91.7 \%$ of normal cases. These findings coincide with the previous descriptions of normal gastric mucosa as seen by magnified NBI and I scan [8]. The normal mucosa by magnified I scan they found normal visible collecting venules and Subepithelial Capillary Net work (SECN) with rounded mucosal pattern of body. It was a comparative study between magnified white light endoscopy and magnified I scan with sensitivity $80 \%$ and sepicivicity $95 \%$ (PPV 98\%) to detect normal gastric body mucosa [7].

In another study the magnified views of gastric corporal mucosa were classified into four patterns (type Z-0, Z-1, Z-2 and Z-3). Type Z-0 pattern (which means rounded mucosal pattern of body with regular arrangement of $\mathrm{CV}$ and SECN) was observed in all normal H. pylori-negative mucosae [8]. In our study we found that the absence of either collecting venule or SECN in the body has a good sensitivity and poor specificity for the diagnosis of HP positive gastritis (sensitivity $93 \%$ and specificity $32 \%$ for $\mathrm{CV}$ and sensitivity $89.1 \%$ and specificity $32 \%$ for SECN) while for combined loss of CV and SECN it was $91 \%$ sensitivity, $26.2 \%$ specificity.

Our result is different from Qing et al., [7] using magnified I scan they showed a sensitivity of $50 \%$ and specificity of $96.8 \%$ for the absence of CV to diagnose HP positive gastritis and sensitivity $95 \%$ and specificity of $93.5 \%$ for combined absence of CV and SECN, yet the low sensitivity of CV loss in Qing et al., [7] study may be attributed to their dependence on RUT to prove or disprove HP rather than pathology which may have affected their result if PPI was administrated, in our study we have solid base of pathological examination for HP positivity.

In a study by using magnified endoscope plus NBI, they described different mucosal pattern (normal gastric body (Type 1) pattern: Honeycombtype Sub-Epithelial Capillary Network (SECN) with a regular arrangement of collecting venules. And regular round pits. (Type 2) pattern comprises a honeycomb SECN with regular, round pits but in the absence of collecting venules. (Type 3) pattern: Loss of normal SECN and collecting venules, with enlarged white pits surrounded by erythema. The sensitivity and specificity for types $2+3$ for the detection of $\mathrm{H}$. pylori infection were $95.2 \%$ and $82.2 \%$, respectively; when type 3 was excluded, the specificity rose to $93.3 \%$ [6]. The significant discrepancy in the results (the low specificity in our study) is probably attributed to the absence of magnified endoscopy. Inflammatory cell infiltration concealed the superficial SECN and CV whatever the cause of inflammation HP positive or negative gastritis. These results highlight the importance of magnified endoscopy and the low utility of I scan alone in detection of HP infection.

\section{References}

1- SUERBAUM S., MICHETTI P., et al.: Helicobacter pylori infection. N. Engl. J. Med., 347: 1175-86, 2002.

2- MEGRAUD F., LAMOULIATTE H., et al.: Review article: The treatment of refractory Helicobacter pylori infection. Aliment. Pharmacol. Therapy, 17: 1333-43, 2003.

3- DINIS-RIBEIRO M., LOPES C., Da COSTA-PEREIRA A., et al.: A follow-up model for patients with atrophic 
chronic gastritis and intestinal metaplasia. J. Clin. Pathol.; 57: 177-82, 2004.

4- McNULTY CAM, LEHOURS P. and MÉGRAUD F.: Diagnosis of Helicobacter pylori infection. Helicobacter; 16 (Suppl. 1): 10-8, 2011.

5- MEINING A., RIEDL B. and STOLTE M.: Features of gastritis predisposing to gastric adenoma and early gastric cancer. J. Clin. Pathol., 55 (10): 770-3, 2002.

6- TAHARA T., SHIBATA T., NAKAMURA M., et al.: Gastric mucosal pattern by using magnifying narrow- band imaging endoscopy clearly distinguishes histological and serological severity of chronic gastritis. Gastrointest Endoscope, 70: 246-53, 2009.

7- QING QING QI, XIU LI ZUO, CHANG QING LI, et al. High-definition magnifying endoscopy with i-scan in the diagnosis of Helicobacter pylori infection: A pilot study. Journal of Digestive Diseases, 14: 579-86, 2013.

8- YAGI K., NAKAMURA A. and SEKINE A.: Characteristic endoscopic and magnified endoscopic findings in the normal stomach without Helicobacter pylori infection. J. Gastroenterol. Hepatol., 17: 39-45, 2002.

\title{
دراسة ملدى فاعلية التصوير بمنظار ايى سكان فى تشخيص إلتهابات المعدة
}

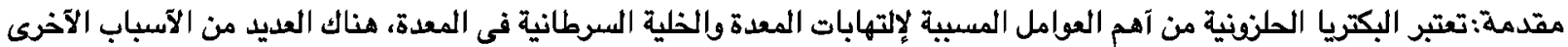

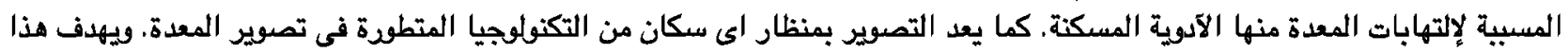

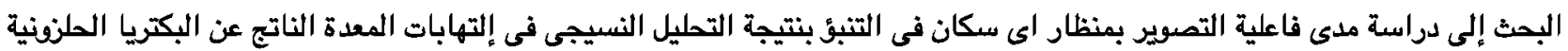

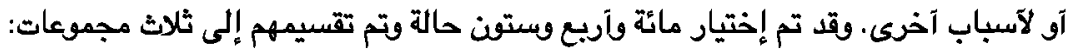

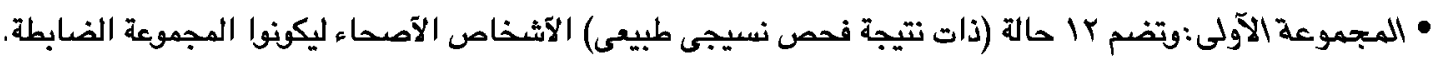 \\ • المجموعة الثانية:وتضم 1 . 1 حالة (إلتهابات المعدة نتيجة البكتريا العلزونية). \\ • المجهموعة الثالثة: وتضم 0 الم حالة إلتهاب معدة نتيجة آسباب آخرى (مثل الآدوية المسكنة). \\ وقد خضعت جميع الحالات إلى الفصص الإكلينيكى، الفحصصات المعملية، دالالات الفيروبسات، الفحص بالموجات الصوتية، والتصوير بمنظار

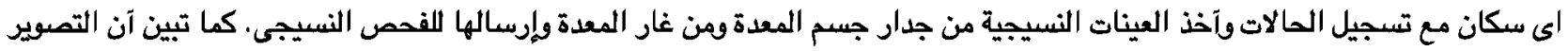

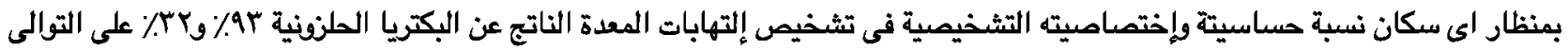 \\ بالمقارنة إلى مجموعة الآصحاء ومجموعة إلتهابات المنعدة سالبة البكتريا الحلزونية. \\ خلصست هذه الرسالة إلى : إرتفاع نسبة حساسيته وقلة إختصاصيتة التثخيصية في تثخيص إلتهابات المعدة الناتج عن البكتريا الملزونية

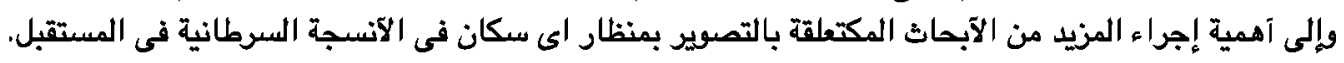

